\title{
Compound Heterozygous C282Y/H63D Mutation in Hemochromatosis: A Case Report
}

\author{
Zazour Abdelkrim*, Wafaa Khannoussi, Amine El Mekkaoui, Ghizlane Kharrasse, Zahi Ismaili \\ Hepato-Gastro-Enterology Unit, Mohammed VI University Hospital Oujda, Oujda, Morocco \\ Email: *zazourabdelkrim1987@gmail.com
}

How to cite this paper: Abdelkrim, Z., Khannoussi, W., El Mekkaoui, A., Kharrasse, G. and Ismaili, Z. (2016) Compound Heterozygous $\mathrm{C} 282 \mathrm{Y} / \mathrm{H} 63 \mathrm{D}$ Mutation in $\mathrm{He}-$ mochromatosis: A Case Report. Open Journal of Clinical Diagnostics, 6, 30-35.

http://dx.doi.org/10.4236/ojcd.2016.63006

Received: July 25, 2016

Accepted: September 18, 2016

Published: September 21, 2016

Copyright $\odot 2016$ by authors and Scientific Research Publishing Inc. This work is licensed under the Creative Commons Attribution International

License (CC BY 4.0).

http://creativecommons.org/licenses/by/4.0/

\begin{abstract}
Hereditary hemochromatosis is a condition characterized by iron overload, which is both treatable and preventable. It's mainly related to hepcidin deficiency related to mutations in genes involved in hepcidin regulation. Iron overload increases the risk of disease such as liver cirrhosis, heart disease and diabetes. Two HFE genotypes have been commonly described in cases of iron overload, C282Y homozygosity and C282Y/H63D compound heterozygoty. The diagnosis of this rare disease now can be explored by biological and imaging tools. We report a case of compound heterozygous C282Y/H63D discovered by family screening for elevated serum ferritin.
\end{abstract}

\section{Keywords}

Iron Overload, Compound Heterozygoty, Phlebotomy

\section{Introduction}

HFE hemochromatosis is a genetic disease related to mutation in HFE gene [1]. Its prevalence in Morocco is unknown and is believed to be rare. In HFE related iron overload, 2 major genotypes have been described: C282Y homozygosity and C282Y/ H63D compound heterozygosity. The prevalence of homozygous C282Y in Caucasians is very high, about 3\% - 5\% [2], and the prevalence of C282Y/H63D compound heterozygosity is 4 times higher [3]. In clinical iron overload and iron overload related disease, the dominant genotype is $\mathrm{C} 282 \mathrm{Y}$, and a small proportion of cases are compound heterozygotes [3]. Though the clinical penetrance of C282Y homozygosity is about $28 \%$ in males and $1 \%$ in females [4], the penetrance of compound heterozygosity is about $13.5 \%[5]$.

It has been recently confirmed that heterozygosity is rarely clinically overt and serum ferritin is higher in this population compared with mutation free controls [6]. The pa- 
thophysiology is better known, and hepcidin deficiency is the main mechanism leading to iron overload [5]. The liver synthesis of hepcidin is decreased and inappropriate to iron burden in case of HFE mutation. The role of hepcidin is to insure the iron homeostasis by regulating ferroportin related intestinal absorption and excretion by the reticuloendothelial macrophages. Plasma iron overload consequent to unregulated intestinal absorption and erythrophagocytosis iron release, lead to high transferrin-iron saturation [TS] and generate a non transferrin bound iron taken by organs, mostly liver, pancreas and heart. Iron deposition in these organs leads in the ultimate stage to organ dysfunction and failure (Figure 1) [7] [8]). In heterozygotes, it is not yet clear if serum ferritin (SF) level $>1000 \mathrm{ng} / \mathrm{ml}$ is isolated risk factor for disease development or associated comorbid factors are necessary [9].

HFE-related hemochromatosis is the classical and first described form of genetic iron overload [10]. The HFE gene located on chromosome 6 codes for the membrane protein HFE, a MCH-like protein whose definite role at the membrane remains unclear [8] [11].

The most frequent and classical mutation of this gene is the p.Cys282Tyr (C282Y) mutation. Prevalence of this mutation is high in Caucasian population (10\% of the subjects are heterozygous, and 3 to 5 subjects per thousand are homozygous), but almost absent in nonwhite populations [11]. Other genotypes commonly included in HFE than C282Y homozygosity cannot explain overt iron overload and do not result in clinically significant iron overload in the absence of cofactors accounting for disturbed iron metabolism (alcoholism or metabolic syndrome): compound heterozygosity C282Y/H63D. However, some subjects with compound heterozygosity, even without known cofactors, increased transferrin-iron saturation and serum ferritin. Other rare HFE mutations have been described associated with those frequent genotypes, thus explaining unusual cases of iron overload: type 2 HJV and HAMP, type 3 TFR2, type 4 ferroportin [11] (Table 1).

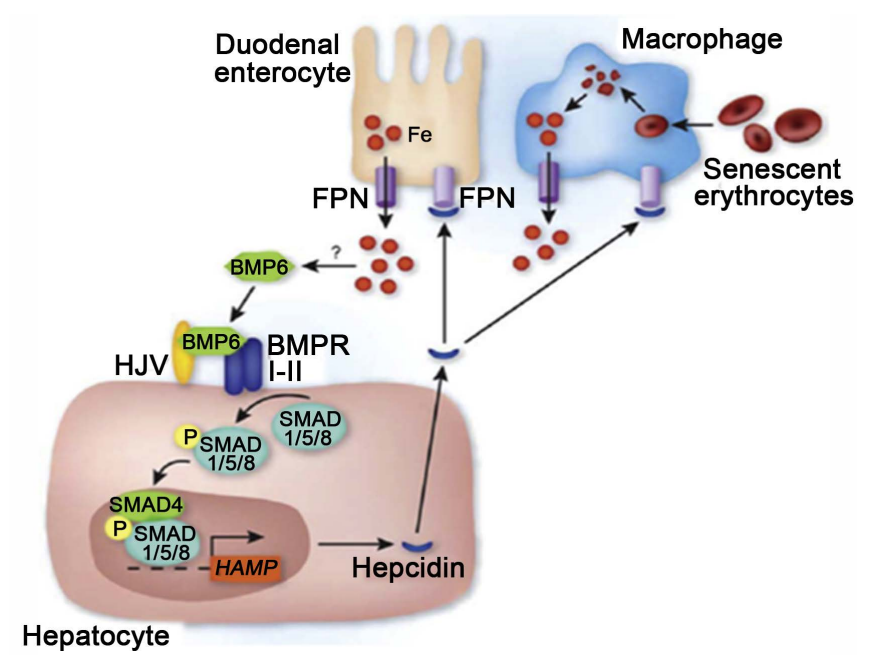

Figure 1. Molecules involved in Iron Metabolism Iron homeostasis as regulated by hepcidin. BMPR; bone morphogenetic protein receptor, FPN; ferroportin, HJV; hemojuvelin; SMAD; Sma and Mad related protein. 
Table 1. Different types of hereditary hemochromatosis according to the genes involved and their classical phenotypes.

\begin{tabular}{cccccccc}
\hline Types & Gene & Age of Onset & Iron Burden & Liver & Bones and Joints & Heart & Pituitary \\
\hline Type 1 & HFE & $\approx 40-60$ & + t++ & ++ & ++ & + & + \\
Type 2A & HJV & $\approx 15$ & +++ & +++ & ++ & +++ & ++++ \\
Type 2B & HAMP & $\approx 15$ & +++ & +++ & ++ & +++ & ++++ \\
Type 3 & TFR2 & $\approx 30$ & +++ & +++ & ++ & + & ++ \\
Type 4A & SLC40A1 & Any & $+/+++$ & $?$ & - & - & - \\
Type 4B & SLC40A1 & Any & $+/+++$ & ++ & - & - & - \\
\hline
\end{tabular}

We report a rare case in our settings of compound heterozygosity C282Y/H63D revealed by family screening treated by phlebotomy.

\section{The Natural History of Disease and Clinical Expression}

-A lag phase (stage 0)

-A biological expression phase, which rarely starts before the age of 20. At this point, the early stigma of excess iron in the body appear and translates into an increase of the coefficient of transferrin-iron saturation (plasma iron overload; stage 1), then the concentration of serum ferritin (Tissue iron overload; stage 2): A phase of clinical expression, manifesting itself by symptoms non-specific occurring usually around the age of 40 years for men and 50 years for women. The disease will first associate signs altering the quality of life of patients (stage 3): asthenia, osteo-articular pain, hepatomegaly, skin hyperpigmentation, heart faillure.

At a more advanced stage (stage 4), it will evolve into abuses that might compromise the prognosis (diabetes, cirrhosis, hepatocarcinoma ...). Hemochromatosis type I is one of the only genetic diseases to benefit from a simple, inexpensive and effective treatment once it is implemented early. The treatment is based on iterative bleedings (phlebotomy) and consists of two phases: a phase of attack (to decrease ferritin in the body) and a maintenance phase (to avoid the re-accumulation of iron). Early support helps prevent the development of irreversible complications and provides patients with a life expectancy similar to that of the general population [4] [6].

\section{Observation}

We report a case of a male patient 56 years old, followed for diabetes mellitus for 6 months with Hbalc within normal range under oral anti-diabetic OAD, his tobacco consumption is 800 cigarettes/year, with no alcohol abuse. His brother 61 years old has a compound heterozygous $\mathrm{C} 282 \mathrm{Y} / \mathrm{H} 63 \mathrm{D}$ hemochromatosis managed with phlebotomy treatment every 2 weeks up to a ferritin to $56 \mathrm{ng} / \mathrm{ml}$ during a phase of attack (the initial serum ferritin $756 \mathrm{ng} / \mathrm{ml}$ ), his sister and mother have diabetes mellitus. The patient was screened for HFE hemochromatosis and was referred to our unit for hyperferritinemia (1102 ng/ml). He was symptoms free and his blood tests revealed transferrin-ironsatu- 
ration at $65 \%$, the blood count was normal as it was for diabetes tests, cholesterol, hemostasis, liver enzymes and renal function. Genetic testing for HFE hemochromatosis concluded to compound heterosigosity C282Y/H63D (Figure 2). Hepatic MRI evaluated iron overload to $230 \mathrm{micromol} / \mathrm{g}+/-50$ (normal <36). Cardiac evaluation found no abnormality, the left ventricular ejection fraction was $62 \%$. The patient has regular phlebotomies (he received 15 sessions of phlebotomy treatment during the attack phase every 3 weeks until a serum ferritin at $43.25 \mathrm{ng} / \mathrm{ml}$ ). Currently, he is on remission with a maintenance phlebotomie every 2 - 4 months), and the follow up is uneventful.
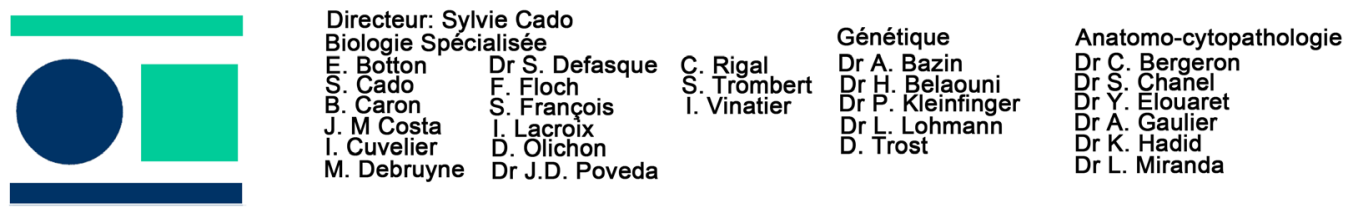

Laboratoire

CERBA
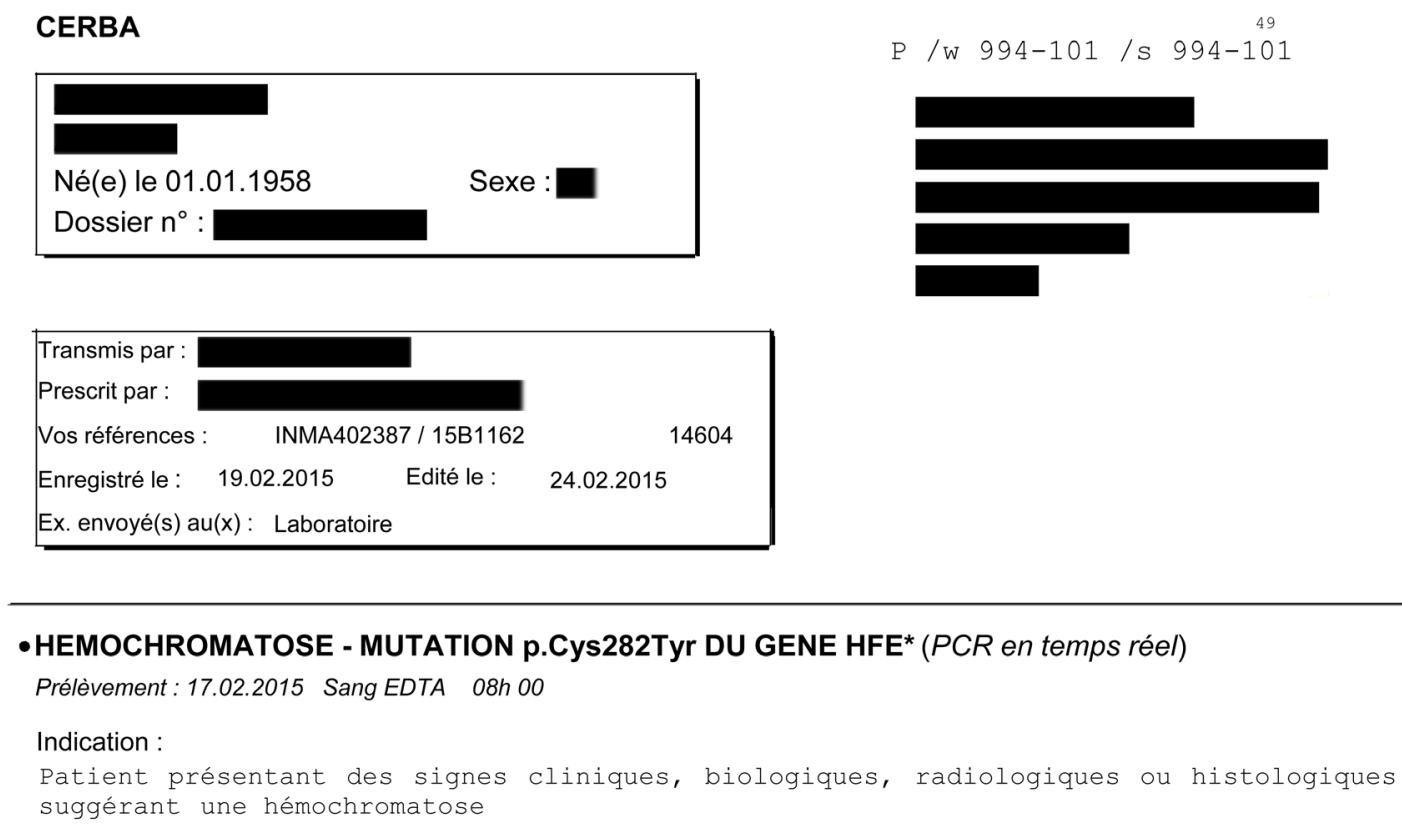

Résultat :

Présence de la mutation à l'état hétérozygote.

Exemplaire destiné au laboratoire préleveur. Nous vous rappelons que, conformément à la législation en vigueur (décret $\mathrm{n}^{\circ} 2008-321$ du 4 avril 2008), seul le médecin prescripteur est habilité à transmettre les résultats au patient.

\section{- HEMOCHROMATOSE - MUTATION p.His63Asp DU GENE HFE* (PCR en temps réel)}

Prélèvement: 17.02.2015 Sang EDTA 08h00

Résultat :

Présence de la mutation à l'état hétérozygote.

Conclusion :

L'hétérozygotie composite p.Cys282Tyr/p. His63Asp est susceptible d'induire une surcharge en fer modérée qui, en règle générale, demeure purement biologique, sans traduction clinique.

Une surveillance régulière des paramètres du métabolisme du fer est préconisée.

Exemplaire destiné au laboratoire préleveur. Nous vous rappelons que, conformément à la législation en vigueur (décret $\mathrm{n}^{\circ}$ 2008-321 du 4 avril 2008), seul le médecin prescripteur est habilité à transmettre les résultats au patient.

Figure 2. Genetic testing for HFE hemochromatosis concluded to compound heterosigosity C282Y/H63D. 


\section{Discussion}

Due to variability in the clinical penetrance of hemochromatosis, visceral iron overload was observed in less than $10 \%$ of patients who are homozygous for the C282Y mutation, with a clinical expression in $24 \%$ to $43 \%$ among males and $1 \%$ to $14 \%$ among women (low percentage of men due to monthly menstruation resulting from a loss of iron and having a protective effect) [11]. While the compound heterozygosity (C282Y/ H63D) patients represent only $5 \%$ of the cases of hemochromatosis [11] [12].

Knowing that heterozygosity $\mathrm{H} 63 \mathrm{D}$ is very common in the general population about 15\% explaining important penetrance of double heterozygote C282Y/H63D [4] [12].

Few studies have focused the pathological value of C282Y/H63D. In the series of the "Health Iron Study Investigators", having brought 242 patients double heterozygote, the importance of body iron overload was assessed biologically (ferritin, transferriniron saturation coefficient). The values were low and stable with age so it is an increase for women after menopause, and the most important values related to the male sex. There was little clinical manifestation of hemochromatosis, which concludes with a low morbidity of the double heterozygosity [8] [13]. However, the authors recognized do not have liver biopsy or MRI for assessment of iron overload order correlate biological markers to the actual overload. In a study conducted in France on 40 patients diagnosed double heterozygote had objectified mean values of the ferritin at $480 \mathrm{ng} / \mathrm{ml}$ and the TSat 50\%, iron overload was assessed by MRI in patients with an average of 119 $\mu \mathrm{mol} / \mathrm{g}$ allowed to the indication of the depleting bleeding in two thirds of cases [2] [4] [12]-[14].

In our case, the importance of iron overload in the body was evaluated biologically and radiologically with very high values (ferritin $>1000 \mathrm{ng} / \mathrm{ml}$, TS $65 \%$ and major liver overload was estimated by MRI at $230 \mu \mathrm{mol} / \mathrm{g}+/-50$ (normal $<36 \mu \mathrm{mol} / \mathrm{g}$ ) which leads us to indicate the phlebotomy treatment (the signed iterative).

\section{Conclusions}

In the literature, the weight of the $\mathrm{C} 282 \mathrm{Y} / \mathrm{H} 63 \mathrm{D}$ genotype in the occurrence in iron overload is very relative and patients with this genotype are less frequent than expected. They are diagnosed at an advanced age and more commonly associated with predisposing factors.

The therapeutic management of patients' compound heterozygosity (C282Y/H63D) is essentially based on the evaluation of iron overload in the body including liver MRI that is a review of reference to detect it.

\section{References}

[1] Feder, J.N., Gnirke, A., et al. (1996) A Novel MHC Class 1-Like Gene Is Mutated in Patient with Hereditary Hemochromatosis. Nature Genetics, 13, 399-408. http://dx.doi.org/10.1038/ng0896-399

[2] EASL (2010) EASL Clinical Practice Guidelines for HFE Hemochromatosis. Journal of Hepatology, 53, 3-22. http://dx.doi.org/10.1016/j.jhep.2010.03.001 
[3] Gurrin, L.C., et al. (2009) HFE C282Y/H63D Compound Heterozygotes Are at Low Risk of Hemochromatosis-Related Morbidity. Hepatology, 50, 94-101.

[4] Deugnier, Y., Barbou-Jecquet, E., et al. (2011) Diagnostic d'une surcharge hépatique en fer. EMC hépatologie. http://dx.doi.org/10.1016/S1155-1976(11)40364-8

[5] D'Alessio, F., Hentze, M.W., et al. (2012) The Hemochromatosis Proteins HFE, TfR2, and HJV from a Membrane-Associated Protein Complex for Hepcidin Regulation. Journal of Hepatology, 57, 1052-1060. http://dx.doi.org/10.1016/j.jhep.2012.06.015

[6] Bacon, B.R., et al. (2011) Diagnosis and Management of Hemochromatosis: Practice Guideline by the American Association for the Study of Liver Diseases.

[7] Salgia, R.J. and Brown, K. (2015) Diagnosis and Management of Hereditary Hemochromatosis. Clinics in Liver Disease, 19, 187-198. http://dx.doi.org/10.1016/j.cld.2014.09.011

[8] Pietrangelo, A. (2015) Genetics, Genetic Testing, and Management of Hemochromatosis: 15 Years since Hepcidin. Gastroenterology, 149, 1240-1251. http://dx.doi.org/10.1053/j.gastro.2015.06.045

[9] Walsh, A., Dixon, J.L., et al. (2006) The Clinical Relevance of Compound Heterozygosity for the $\mathrm{C} 282 \mathrm{Y}$ and H63D Substitution in Hemochromatosis. Clinical Gastroenterology and Hepatology, 4, 1403-1410. http://dx.doi.org/10.1016/j.cgh.2006.07.009

[10] Pietrangelo, A. (2007) Hemochromatosis: An Endocrine Liver Disease. Hepatology, 46, 1291-1301. http://dx.doi.org/10.1002/hep.21886

[11] Bardou-Jacquet, E. and Brissot, P. (2014) Diagnostic Evaluation of Hereditary Hemochromatosis (HFE and Non-HFE). Hematologyl Oncology Clinics of North America, 28, 625-635. http://dx.doi.org/10.1016/j.hoc.2014.04.006

[12] Bardou-Jacquet, E., et al. (2013) Non-HFE Hemochromtosis: Pathophysiological and Diagnostic Aspects. Clinics and Research in Hepatology and Gastroenterology, 38, 143-154.

[13] Zaloumis, S.G., et al. (2015) The Natural History of HFE Simple Heterozygosity for C282Y and H63D: A Prospective Twelve Year Study. Journal of Gastroenterology and Hepatology, 30, 719-725. http://dx.doi.org/10.1111/jgh.12804

[14] Bouizergarène, P., et al. (2006) Les hémochromatoses héréditaires lièe au HFE.

\section{Submit or recommend next manuscript to SCIRP and we will provide best service for you:}

Accepting pre-submission inquiries through Email, Facebook, LinkedIn, Twitter, etc. A wide selection of journals (inclusive of 9 subjects, more than 200 journals)

Providing 24-hour high-quality service

User-friendly online submission system

Fair and swift peer-review system

Efficient typesetting and proofreading procedure

Display of the result of downloads and visits, as well as the number of cited articles

Maximum dissemination of your research work

Submit your manuscript at: http://papersubmission.scirp.org/

Or contact ojcd@scirp.org 